\title{
5 \\ What is the policy significance of the hybrid economy?
}

\author{
Nicolas Peterson
}

\section{Introduction}

The future of Aboriginal people living on remote lands either in the large ex-mission and government communities or in small outstations is problematic both for government and ultimately for the people themselves. Not only are these people remote from mainstream economic activity in many, but by no means all cases, but, by and large, there is no regional demand for their labour. Were people much better educated, perhaps 15-25 per cent could be employed in administration and service delivery in their communities, if all jobs were Aboriginalised. Such a situation is at least a generation or two away even from the possibility of realisation. This situation parallels the situation in a number of countries such as South Africa and parts of Asia where there are also populations that are surplus to the labour requirements of the mainstream economy. The prospects of substantial proportions of the remote Aboriginal population ever being employed in the mainstream are remote.

This faces policymakers, and the people themselves, with the question as to whether there are desirable long-term forms of dependency that are not only satisfactory to Aboriginal people but which are not 
going to be a cause of concern to others, and to ask what resources Aboriginal people might have to draw on to structure such a life (cf. Ferguson 2013).

Since at least 2001 Jon Altman has been a strong advocate of one possible solution for some of those people living on Aboriginal lands in the tropical savannah and coastal areas of north Australia. His solution is for the government to recognise that these people are part of what he calls a hybrid economy and for the government to support a particular sub-group to build on this for an alternative development paradigm that is more accepting of cultural difference (Altman 2010: 270). The thinking behind this idea goes back to at least his experience and research for his $\mathrm{PhD}$ thesis in 1979-80 living at Mumeka (Momega) outstation south of Maningrida, with a small, fluctuating population averaging 19 people. In a fine study he documented the income and expenditure patterns and the time allocation of people living there, quickly coming to appreciate the value and significance of the customary economy (see Altman 1987).

On the basis of extended fieldwork at Mumeka outstation in western Arnhem Land, Altman estimated that the imputed value of subsistence income (i.e. hunted and gathered foods at the outstation) was 175 per cent of the people's cash income. Clearly this was a major contribution to people's livelihood and fundamental to understanding their circumstances at that time. The outstation life provided a much better protein diet and much less stress than living at Maningrida.

Jon developed the term 'hybrid economy' in 2001 during his collaboration with the members of the Key Centre for Tropical Wildlife Management at Charles Darwin University, emphasising that the notion of Aboriginal economy in remote Australia needed to be broadened and developed especially because both policymakers and politicians failed to understand the important contribution that remote area Aboriginal people make to their own support: they are not just welfare dependent but contribute to their own support through the production of bark paintings and artefacts for sale, and through hunting, foraging and fishing for food.

Since developing the framework he has been strongly promulgating it in both academic and applied forums. From 2007 he has elaborated his ideas under the project title People on Country: Healthy Landscapes 
and Indigenous Economic Futures. This refers to what Altman describes as a social and environmental movement based around the recognition of how much of the national environmental estate and biodiversity is on Aboriginal lands. Further, he argues that across this Indigenous estate are many hundreds of small communities that are in an ideal position, properly supported by government, to help look after it both in their own interests and those of the nation.

The Northern Territory Emergency Response in 2007 is a key turning point in Altman's work. This is marked by outspoken criticism of the government's approach in Indigenous affairs and 'a growing disenchantment with the ability of evidence based research to inform productive Indigenous policy and practice' (Thomassin \& Butler 2014: 4). Altman saw Indigenous affairs as increasingly influenced by particular ideologies and interest groups. For 30 years Altman has devoted himself to the production of high quality evidenced-based research, both by himself and through the Centre for Aboriginal Economic Policy Research (CAEPR), directed to the betterment of Aboriginal lives by assisting government and others in the formulation of policy in Indigenous affairs.

There is no doubt that Altman's work has been enormously effective in developing understanding of the nature and significance of, and securing support for, outstations, the art and craft movement, Indigenous tourism projects and, more recently, ranger programs and other aspects of working on country. He has also been a strong advocate for the Community Development Employment Projects (CDEP) scheme, so mistakenly criticised and attacked by many.

Given that Altman is now in full advocacy mode for the significance of the hybrid economy, not just as a framework for describing the economies of remote Australia but as the basis for policy, I want to ask whether the thinking behind the hybrid economy holds out the promise of a desirable form of long-term dependency and if it is really coherent as a basis for policymaking for Aboriginal people in remote Australia. 


\section{The hybrid economy}

The hybrid economy is usually presented in the form of a Venn diagram of three intersecting circles, one representing the economic aspects of the state, another representing the market and the third the customary economy. This gives rise to four intersections between these three sectors $(4,5,6,7$ in Fig. 5.1) and it is the linkages indicated by these intersections that highlight the areas where Altman considers the most productive activity occurs (Russell 2011:2).

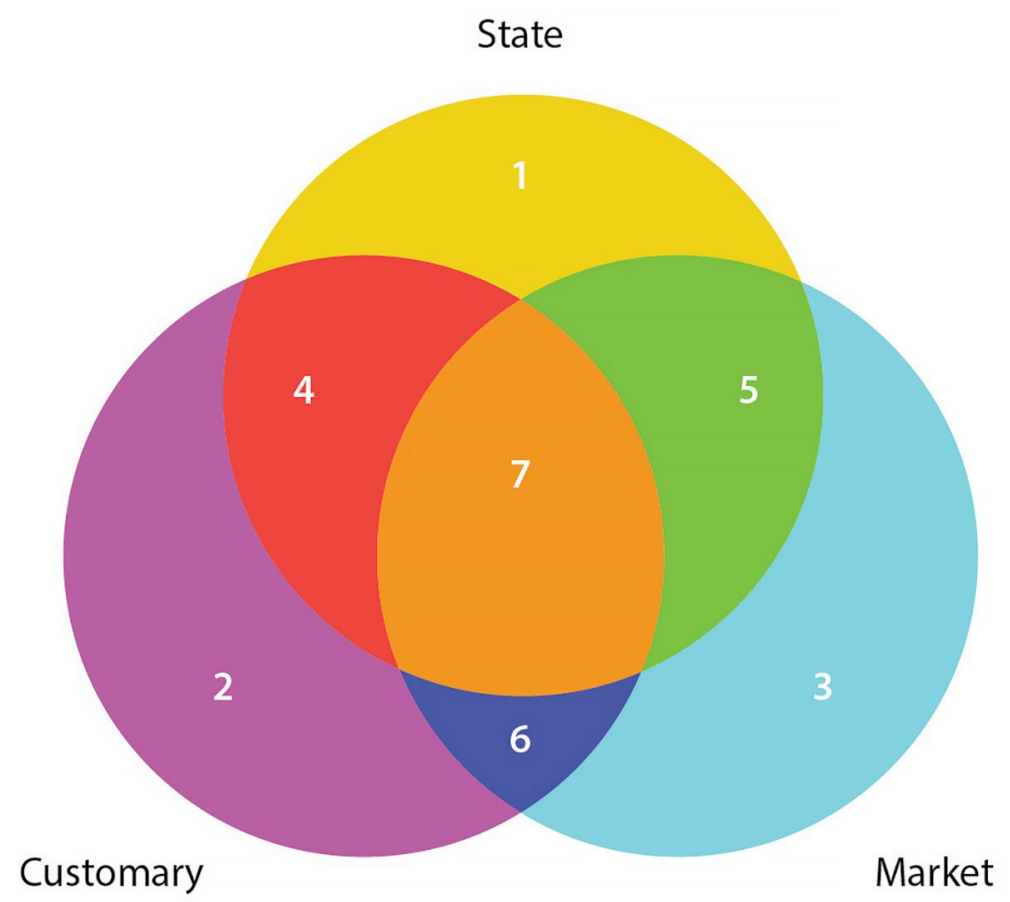

Fig. 5.1 The hybrid economy

Source: Altman (2005)

Thus in respect of the intersection between the customary and the state (4), social security or the CDEP scheme underwrite some customary activities; in respect of the intersection between the state and the market (5) there are commercial enterprises that are underwritten by the state through CDEP or other enterprise support; in respect of the intersection between the customary and the market (6) there are joint ventures that are not predicated on any state support; 
and in respect of the intersection between market, state and customary (7) the clearest example is the marketing of arts and crafts but also cultural tourism and some environmental services (Altman 2001: 4-5). The model could be further developed and is not always consistently presented (see Gregory, this volume). In many illustrations the three domains vary in size, as does the extent of the overlaps, and generally speaking there is a lack of quantification associated with the sectors and overlaps.

\section{The hybrid economy: A desirable long-term form of dependency?}

The hybrid economy model focuses on production and income sources. Thus the state (1) mainly supplies direct income in the form of social security payments and, in the outstation contexts, a limited number of jobs. The customary sector (2) mainly provides imputed income through import substitution as a result of hunting and fishing. The market sector (3) provides cash through the sale of artefacts. In the outstation contexts segments 4, 5, 6, and 7 are mainly related to the generation of income through the production and sale of artefacts subsidised through the CDEP scheme, occasional involvement in tourism, and more recently through wages earned in relation to the provision of environmental services.

A central issue is the robustness of the hybrid economy. Does the customary sector continue to play the same important role in import substitution today when there are greater constraints on hunting than in the past, and possibly depletion? The imputed contribution to income in Mumeka, at least, seems to have dropped.

This might not be an issue if jobs have become available in the environmental services area, but given the limited number of such jobs available in the Maningrida area (around 40) the possibilities for increased cash income from this source seem small. There are certainly opportunities for increased tourism ventures but only a limited number of these could possibly function in the range of one regional centre. As to the art and craft market this can be very valuable but is quite fragile, as Altman has documented, and highly dependent on government funding of the relevant infrastructure. 
The principal source of cash income in the hybrid economy has always been social security, which depends substantially on the age structure and composition of the population. Given that outstation populations are groups of closely related kin, sharing practices are likely to ensure that everybody has some access to cash and in-kind resources. So while the actual mechanisms and tensions in distribution are not known it can be assumed that sharing practices will, generally speaking, ensure a level of access by all.

The most obvious challenge to long-term satisfaction with this existence is in respect of consumption. As long as people's consumer dependency remains low then the levels of income generated by the ever-changing nature of the hybrid economy are likely to remain satisfactory. However, there is evidence of an increased desire for a wider range of goods and services in outstations that require cash. This suggests that levels of consumer dependency are rising. Housing is one example. People's desire for better accommodation is faced with the costs of providing it in remote locations, with consequent declarations by government that no new houses will be built in such places. But there are other expensive and new dependencies, especially associated with the phone and other information and communication technology, the costs of which will, in all probability, rise. Any decline in food from the customary economy will ratchet up the need for cash. Further, people are now being asked to contribute to the cost of services being supplied to them. Together, these factors will diminish outstation residents' discretionary income.

There is good evidence that people in outstations flourish in a number of ways, including in terms of physical and mental health and socially in terms of greatly increased control over their lives (e.g. see Burgess et al. 2009). Outstations probably are a desirable long-term form of dependency for those people living on them. This leads to the question of how many people that involves and foreshadows another: why, if it is desirable, does only a small proportion of the remote population appear to think so? 


\section{How many people live on outstations?}

The difficulties of estimating outstation populations are several. Not least is the high level of mobility between outstations in a region and the regional centre, an issue that has been present since Altman carried out his fieldwork (see also Taylor 2006: 49). Then there is the issue of the definition of outstation which, as far as the statistical and legal agreements between the Northern Territory and Commonwealth go, is highly confusing, as any residence group outside the core 70 or so designated townships is called an outstation. This leaves not only ample room for confusion but also considerable scope for ambiguity in claims made for the numbers of people covered by the hybrid economy.

In 2001 the number of discrete Aboriginal communities Australiawide was 1,216. Of these, 577 had 19 or less people and 785 had less than 49 (Taylor 2006: 47). It is not clear from these figures how vacant outstations were or are dealt with in these calculations. Such outstations can range from a few tin sheds to very sophisticated housing which may be vacant for years at a time, as is the case in the 19 outstations around Yuendumu and some outstations in Arnhem Land.

The total population of these 'less than 49 people' outstations in 2006 was estimated at 11,343 out of a very remote region total population of 80,680 (Taylor 2006: 47). The high level of mobility between regional centres and outstations can be seen in two different lights. It can be used to argue that many more than simply the residents of the outstations benefit from them, as people whose permanent residence is in the regional centres can go out to an outstation from time to time for recreation and holidays, thus spreading their benefit. But it can also be seen as a potential sign of weakness in the permanency of the outstations in that the regional centres have the enduring resources, services and many other attractions. Orbiting from outstations can lead to people getting stuck in the regional centres.

Either way, outstations (and providing environmental services from them) are a Rolls-Royce option for a very small portion of the Aboriginal population in remote areas. But, as has been suggested, there is some reason to suppose that the viability of outstations is quite fragile, even if government policy remains unchanged. 


\section{A coherent basis for policy?}

In 2005 Altman and Morrison argued that the proper foundation for Indigenous economic development will need to be on the basis of property rights in commercially valuable assets like water, fisheries and minerals (Altman \& Morrison 2006: 52). Elsewhere Altman has emphasised the carbon economy: the payment of rent to traditional owners by government and others for use of land. As with the hybrid economy, the emphasis is on income which underwrites Aboriginal people's own unilateral definition of economic development objectives (Altman 2012: 16). Apparently this is a right that Indigenous Australians have. The basis for this right or the responsibilities that go with it is nowhere stated, nor are there any indications of substantively worked out economic development objectives for particular remote regions. Further, there is no indication of why increasing unearned income will not result in increased dependency. The implied image is of a rentier class. But what this leisured people would do with their income and time is never addressed, although what past experience suggests is not good.

A further cloud reducing the clarity of the policy implications of the hybrid economy is the emphasis placed on the significance of cultural difference. The specific nature of cultural differences relevant to Aboriginal life in the 21 st century to be built on or accommodated are not spelt out. Further, the emphasis on culture is often in danger of being backward-looking and failing to acknowledge the huge changes that have taken place in the last 60 years. There is no reason to suppose that the rate of change will decrease, although its trajectory is hard to predict. By emphasising cultural issues, the much more complex sociological ones are avoided and discussion of the future becomes slogans that get in the way of clear, evidenced-based argument, analysis and thinking.

The positive intentions behind the promotion of the hybrid economy cannot be questioned, but at best it is only focusing on the easy stuff and avoiding dealing with any of the difficulties the majority of remote area populations are facing. One obvious reason for doing so is that Altman, like everybody else, Aboriginal or non-Aboriginal, has no clear ideas about what to do for the majority of the population. We all wish people in remote Australia a good life but what that might be and 
how to secure it is another question altogether. Some people, however, do not have the luxury of doing nothing about the future-they are the government and the policymakers. Altman is an influential commentator from among one important set of opinion makers who all want things done-church members, the medical profession, Aboriginal and other public intellectuals, and members of the United Nations are others. They mainly work in slogans or critiques of existing policy, offering palatable but implausible solutions such as suggesting that all that is required is to listen to Aboriginal people. Were it so easy. If we look at what Aboriginal people in remote Australia actually do, it is clear that working in the customary economy and living on an outstation is only desirable for a small proportion of the total population. Helping the majority to develop desirable long-term life projects under conditions of dependency is clearly going to be highly challenging.

\section{Acknowledgements}

I would like to thank Jon Altman, Maggie Brady, William Arthur, David Martin, Julie Finlayson, Paul Burke, Chris Gregory and Francesca Merlan for many stimulating conversations around topics related to this contribution.

\section{References}

Altman JC (1987). Hunter-gatherers today: an Aboriginal economy in north Australia, Australian Institute of Aboriginal Studies, Canberra.

Altman JC (2001). Sustainable development options on Aboriginal land: the hybrid economy in the twenty-first century, Discussion Paper 226, Centre for Aboriginal Economic Policy Research, The Australian National University, Canberra.

Altman JC (2005). Economic futures on Aboriginal land in remote and very remote Australia: hybrid economies and joint ventures. In Austin-Broos D \& Macdonald G (eds), Culture, economy and governance in Aboriginal Australia, University of Sydney Press, Sydney. 
Altman JC (2010). What future for remote Indigenous Australia? Economic hybridity and the neoliberal turn. In Altman JC \& Hinkson M (eds), Culture crisis: anthropology and politics in Aboriginal Australia, UNSW Press, Sydney.

Altman JC (2012). People on country as alternate development. In Altman JC \& Kerins S (eds), People on country: vital landscapes, Indigenous futures, The Federation Press, Sydney.

Altman JC \& Kerins S (eds) (2012). People on country: vital landscapes, Indigenous futures, The Federation Press, Sydney.

Altman JC \& Morrison J (2006). Enhancing economic independence. Journal of Indigenous Policy 5:48-53.

Burgess C, Johnston F, Berry H, McDonnell J, Yibarbuk D, Gunbarra C, Mileran A \& Bailie R (2009). Healthy country, healthy people: the relationship between indigenous health status and 'caring for country'. Medical Journal of Australia 190(10):567-72.

Ferguson J (2013). Declarations of dependence: labour, personhood, and welfare in southern Africa. Journal of the Royal Anthropological Institute 19(2):223-42.

Russell S (2011). The hybrid economy topic guide, Centre for Aboriginal Economic Policy Research, The Australian National University, Canberra.

Thomassin A \& Butler R (2014). Engaging indigenous economy: a selected annotated bibliography of Jon Altman's writings 19792014, Working Paper 96, Centre for Aboriginal Economic Policy Research, The Australian National University, Canberra.

Taylor J (2006). Population and diversity: policy implication of emerging indigenous demographic trends, Discussion Paper 283, Centre for Aboriginal Economic Policy Research, The Australian National University, Canberra. 
This text is taken from Engaging Indigenous Economy: Debating diverse approaches, edited by Will Sanders, published 2016 by ANU Press, The Australian National University, Canberra, Australia. 